\title{
Evaluation of Antioxidants, Antidiabetic, Antiinflammatory Active Compounds from Leptogium rivurale Through In-Vitro and In-Silico Studies
}

\author{
Prakash Pandurangan ${ }^{1}$, Bommana Chanakya ${ }^{1}$, Nagaraj RajaPrabu ${ }^{2}$, Shobana ${ }^{3}$, N. Uthralakshmi ${ }^{1}$, \\ Saigeetha S ${ }^{1}$, Antony V Samrot ${ }^{4, *}$ (iD \\ 1 Department of Biotechnology, Sathyabama Institute of Science and Technology, Chennai, Tamil Nadu - 600 119, India \\ 2 Biomedical Research Laboratory, Department of Botany, School of Bioscience, Bharathiar University, Coimbatore - \\ 641046, Tamil Nadu, India \\ 3 Department of Genetic Engineering, SRM Institute of Science and Technology, Chennai, Tamil Nadu, India \\ 4 School of Bioscience, Faculty of Medicine, Bioscience and Nursing, MAHSA University, Jalan SP2, Bandar Saujana \\ Putra, 42610, Jenjarom, Selangor, Malaysia \\ * Correspondence: antonysamrot@gmail.com (A.V.S.);
}

Received: 11.08.2021; Revised: 1.10.2021; Accepted: 5.10.2021; Published: 31.10.2021

\begin{abstract}
Leptogium rivurale is a flooded jelly skin lichen as the surface becomes jelly on wet. It is a cyanolichen with a cyanobacterium Nostoc. In this present study, Leptoguium rivurale were collected from Kodaikanal and extracted using methanol and distilled water. Qualitative analysis of phytochemicals from the extracts showed the presence of carbohydrates, glycosides, phenols, terpenoids, saponins, and proteins. The methanol extract was found to inhibit the $\alpha$-amylase enzyme activity better than aqueous extract. The methanol extract was found to have better DPPH radical scavenging activity and anti-inflammatory activity than aqueous extract. Then the extract was subjected to GC-MS analysis. The molecules obtained through GC-MS analysis were subjected to in-silico molecular docking simulation using AutoDock software. Cyclohexanol and oxirane were the potential drug candidates identified.
\end{abstract}

Keywords: Leptogium rivurale; antioxidants; antidiabetic; anti-inflammatory.

(C) 2021 by the authors. This article is an open-access article distributed under the terms and conditions of the Creative Commons Attribution (CC BY) license (https://creativecommons.org/licenses/by/4.0/).

\section{Introduction}

Inflammation is a healing process wherein chronic inflammation causes rheumatoid arthritis, cancers, obesity, etc. [1]. There are remedies to combat inflammation once such are microbes-derived metabolites, vitally used in the medical field. They address problems from environmental clean-up to treating diseases. Microbes show enhanced activities when associated with other microbes of different community communities, including mycorrhiza, Azolla, and lichens [2].

Lichens are composite organisms that comprise algae or cyanobacteria living among the filaments (hyphae) of the fungi exhibiting symbiotic relationships [3]. The dominating partner fungus gives lichens most of its features. The alga can be either a green alga or a bluegreen alga, otherwise known as cyanobacteria and most of the lichens have both types of algae[4]. Apart from having the ability to survive in a harsh environment, Lichens possess the capability to absorb everything in their atmosphere, especially pollutants, thereby acting as one 
of the indicators of environmental condition. The total numbers of lichens species are 18,500 are reported in the world [5].

Lichens grow on rocks, plastics, tree bark, leaves, etc. Among lichens, Leptogium is a genus belonging to the family Collemataceae. It appears to be blue-grey to brown blackish with the jelly-like surface in wet conditions [6-10]. This is associated with a cyanobacterium belonging to the genus Nostoc. The secondary metabolites produced by lichens possess significant biological activities like antimicrobial, antioxidant, antiviral, antiproliferative, and anti-inflammatory activities [11-13]. This study aims to extract and identify bioactive compounds from Leptogium spp and evaluate the bioactivity of these compounds, especially anti-inflammatory activity by in vitro and in silico analysis.

\section{Materials and Methods}

\subsection{Sample collection and extraction.}

The sample was collected from Kodaikanal, India, in sterile polythene bags, thoroughly washed with tap water, and shade dried. $50 \mathrm{~g}$ of dried sample was taken in two conical flasks. $50 \mathrm{ml}$ of methanol was added to one flask and another with $50 \mathrm{ml}$ of distilled water. The soaked samples were placed in a shaker for three days. After 3 days, it was centrifuged at $10000 \mathrm{rpm}$ for $10 \mathrm{~min}$. The supernatant from the methanolic extract was taken and evaporated in a Petri plate in a fume hood, whereas water extract was subjected to lyophilization. Thus, prepared extracts were stored at $4{ }^{0} \mathrm{C}$ till further use.

\subsection{Phytochemical screening and quantification.}

Phytochemical examinations were carbohydrates, alkaloid, Glycosides, saponins, protein, etc. were performed following the [14]. Further, the lichens extract were subjected to quantify carbohydrates by Anthrone method, Protein content by Lowry's method [15], and phenol content by Folin-Ciocalteu assay [16].

\subsection{Antioxidant activity by DPPH method.}

The free radical scavenging activity of the ethanol extract was measured by 1,1diphenyl-2-picrylhydrazyl (DPPH) [14].

\subsection{Estimation of antidiabetic activity by $\alpha$-amylase inhibition assay.}

$\alpha$-amylase inhibitory activity of methanol and aqueous extract was carried out according to the standard method [17].

\subsection{Estimation of anti-inflammatory activity by egg albumin denaturation assay.}

Egg albumin denaturation activity of methanol and aqueous extracts was carried out according to standard method with minor modifications [18]; the reaction was prepared by adding $0.5 \mathrm{ml}$ of egg albumin and $1.5 \mathrm{ml}$ of phosphate buffer saline (PBS, 0.02mol/L, $\mathrm{pH} 6.8$ ). Various concentrations of sample $(10,20,40,60,80,100 \mu \mathrm{g} / \mathrm{ml})$ of both extracts were added (as separate reaction) and incubated at $37{ }^{\circ} \mathrm{C}$ for $15 \mathrm{~min}$. Then the reaction mixture was heated at $70{ }^{\circ} \mathrm{C}$ for $10 \mathrm{~min}$. The absorbance at $660 \mathrm{~nm}$ was recorded by a spectrophotometer after the reaction mixture was cooled down. The inhibition of percentage was calculated [18]. 
2.6. Thin-layer chromatography.

Commercial TLC plates made with silica gel on aluminum foil were used [19-22]. Where 2:1 chloroform and methanol were used as mobile phase. Following separation, the plate dried; the spots were detected under UV light. Rf value was calculated.

\subsection{GC-MS analysis.}

The GC-MS analysis of the extract was carried out using a Triple quadrupole mass spectrometer with Fused silica $30 \mathrm{~mm}$ of the length of the capillary column, diameter and film thickness is $0.25 \mathrm{~mm}$, where the condition was set as described previously [23].

\subsection{Molecular docking.}

Molecular docking is the in-silico technique used to determine the binding affinity between the optimum ligand and the target receptor, which is a protein the majority of times. The lichen Leptogium rivurale showed high ani-inflammatory activity through in-vitro studies. Hence, the docking is done with receptor target as an enzyme involved in the inflammation process in the human body, and the selected ligands are the molecules obtained in GC-MS analysis. The compound identified from the GC-MS analysis used in this study was nitric oxide synthase enzyme (iNOS) complexed with imidazole (PDB ID 3EJ8). AutoDock 4.6 tools were utilized, and docking simulation was done as previously reported [24].

\section{Results and Discussion}

Microbial products are highly potent active compounds since secondary metabolites have more potential than primary metabolites. Lichen metabolites are different than normal microbes because lichens are associated with fungi and algae. These metabolites are exhibiting excellent bioactive compounds in terms of antioxidants, anticancer, antimicrobial, antidiabetic and anti-inflammatory activities, etc. [25-27]. In this study, Leptogium rivurale metabolites were extracted by aqueous and methanol extractions. This study reveals that lichens have a specific phytochemical activity exhibited in a screening of phytochemicals (Table 1). Aqueous and methanol extracts showed carbohydrates, glycosides, phenol, terpenoids, steroids, tannin, alkaloids, and protein. Among them, steroids, tannins, and alkaloids were absent in both extracts. Rashmi et al. [28] suggested methanol is highly polar to dissolve most of the secondary metabolites of lichens. Few previous studies support this study that reported the presence of alkaloids, saponins, tannins, and terpenoids in the methanolic extracts of macro lichen Ramalina conduplicans [29].

The proximate composition of Leptogium rivurale was evaluated, and results are shown in Figure 1. Total carbohydrates, crude protein, and total phenol content from methanol and aqueous extracts. Carbohydrates are a function of cell energy and cell structural components. It is a major component of lichen species, including $P$. tinctorum, Parmotrema pseudotinctorum, etc. [30]. Carbohydrate and protein content was found to be a little high in aqueous extracts than methanol extract (Figure 1). Certain lichen species recorded high crude protein content [31]. In this present study, the highest level of total phenolic contents observed in the aqueous extract was $20.4 \%$, whereas the methanol extract had $13.5 \%$ (Figure 1). A similar study was carried out by Aoussar et al. [32] with acetone extract of $P$. furfuracea, which 
showed much antioxidant activity. Parizadeh and Garampalli [33] reported $2.96 \mathrm{mg} / \mathrm{g}$ of phenolic content in Leptogium sp.

Table 1. Qualitative analysis of phytochemicals from Leptogium rivurale.

\begin{tabular}{c|l|c|c} 
S. No & Phytochemicals & Aqueous Extracts & Methanol Extracts \\
\hline 1 & Carbohydrates & ++ & +++ \\
\hline 2 & Glycosides & ++ & +++ \\
\hline 3 & Phenol & + & ++ \\
\hline 4 & Terpenoids & + & ++ \\
\hline 5 & Saponins & ++ & +++ \\
\hline 6 & Steroids & - & - \\
\hline 7 & Tannin & - & - \\
\hline 8 & Alkaloids & - & +++ \\
\hline 9 & Proteins & ++ &
\end{tabular}

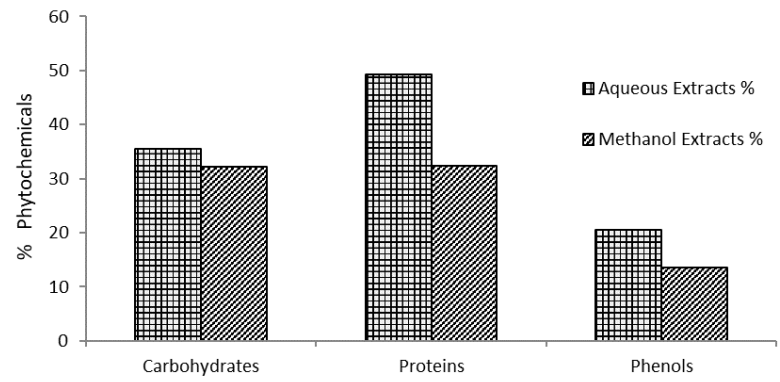

Figure 1. Quantitative estimation of Carbohydrates, Proteins, and Phenols from Leptogium rivurale.

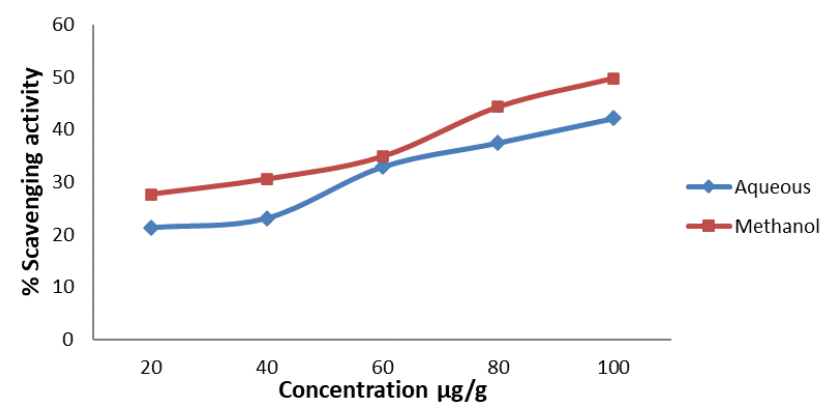

Figure 2. Estimation of antioxidant activity.

Nearly 65 antioxidants compounds were extracted from Lichens substances [26], where the antioxidant activity act through electron-donating substituents and their mutual positioning on the aromatic ring [34]. The scavenging DPPH radicals of the studied L. rivurale extracts are shown in Figure 2. Both the aqueous and methanol extracts of L. rivurale showed a good scavenging activity $\mathrm{EC}_{50}=42.2 \mu \mathrm{g}$ and $\mathrm{EC}_{50}=49.8 \mu \mathrm{g}$, respectively (Figure 2). Kosanić et al. [34] estimated Lasallia pustulata to have better antioxidant activity.

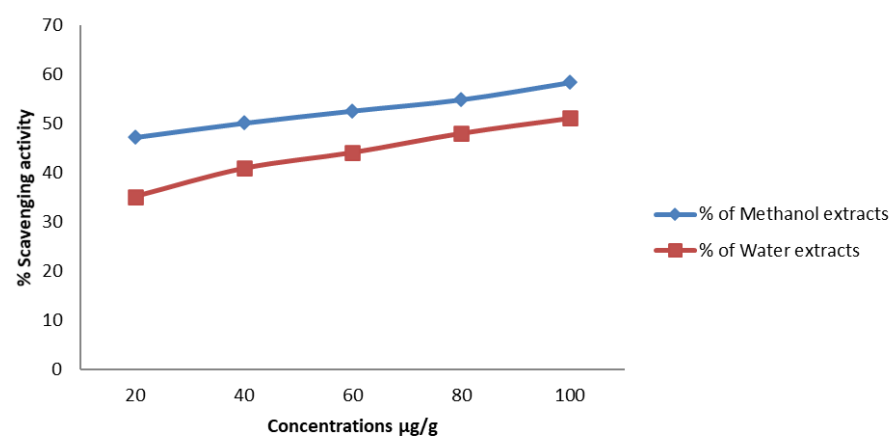

Figure 3. $\alpha$-amylase inhibition activity of $L$. rivurale. 
L. rivurale was showing antidiabetic activity through inhibition of $\alpha$-amylase activity (Figure 3). $\alpha$-amylase is an important enzyme involved in carbohydrate digestion. It hydrolyses the starch and is converted into glycogen and maltose, which exhibits increased blood sugar. Diverse lichens species have anti-diabetic potential activity [35].

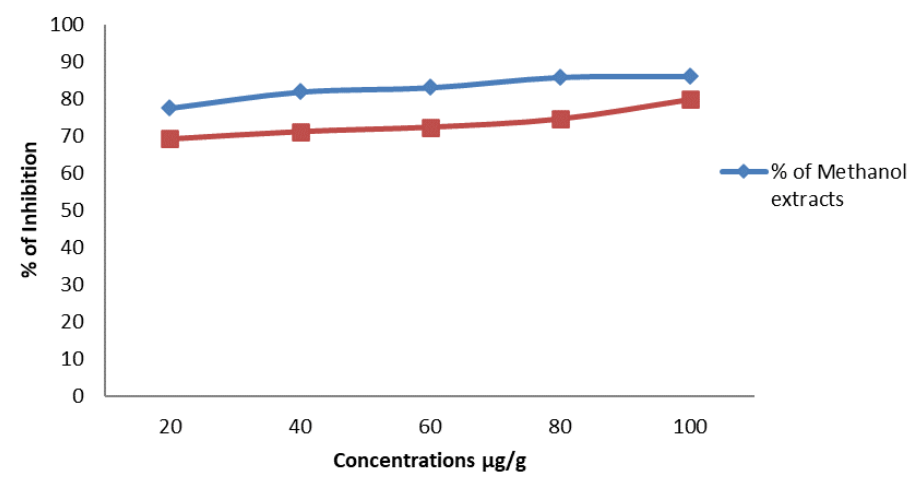

Figure 4. Inflammation inhibition activity of L. rivurale.

Methanol extract of $L$. rivurale showed maximum inflammation inhibition activity at $86.01 \%$, while it was minimum in the aqueous extract $(79.8 \%)$ (Figure 4$)$.

Thin-layer chromatography (TLC) is a good choice to identify the components [36]. Methanol extracts showed three bands with $\mathrm{Rf}$ values $0.95,0.75$, and 0.62 , and aqueous extract showed Rf values were 0.69, 0.59, and 0.45 (Table 2). Different bioactive compounds were determined by GC-MS (Figure 5 and Table 3 ).

Table 2. Thin Layer Chromatography.

\begin{tabular}{c|c|c|c|c} 
S.no & Extracts & Rf value & Rf value & Rf value \\
\hline 1 & Methanol extract & 0.95 & 0.75 & 0.62 \\
\hline 2 & Aqueous extract & 0.69 & 0.59 & 0.45
\end{tabular}

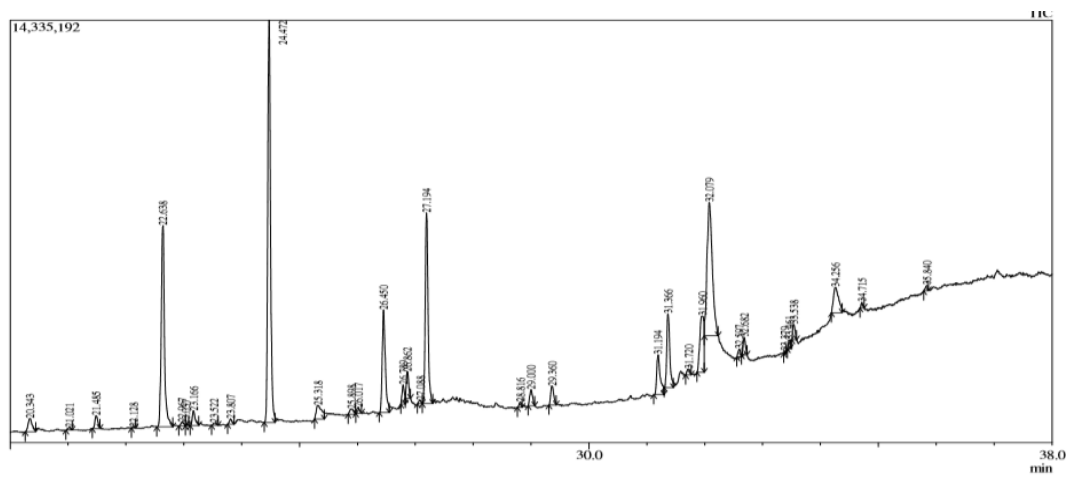

Figure 5. GC-MS analysis of extract.

Table 3. Compounds present in the extract and their bioactivity

\begin{tabular}{c|c|c} 
S.no & Compounds & Bioactivity \\
\hline 1 & Neophytadiene & $\begin{array}{c}\text { Anti-inflammatory, analgesic, } \\
\text { and antipyretic activities } \\
{[37]}\end{array}$ \\
\hline 2 & Hexadecanoic acid, methyl ester & $\begin{array}{c}\text { Antibacterial and antifungal } \\
\text { activities [38] }\end{array}$ \\
\hline 3 & Octadecanoic acid & Antimicrobial [39] \\
\hline 4 & Glycidyl palmitate & $\begin{array}{c}\text { Preparation of isophosphatidic } \\
\text { acid which inhibits apoptosis } \\
\text { [40] }\end{array}$ \\
\hline 5 & 2-methyloctacosane & Antifungal activity [41] \\
\hline 6 & Cyclohexanol & Antimicrobial and cytotoxic \\
& & activities [42]
\end{tabular}




\begin{tabular}{c|c|c} 
S.no & Compounds & Bioactivity \\
\hline 7 & Oxirane & Anti-bacterial activity [43]. \\
\hline 8 & oL & Antimicrobial, anticancer, anti- \\
& inflammatory, anti-diuretic \\
& & activities \\
& [44].
\end{tabular}

L. rivurale extract's GCMS report showed antimicrobial activity of essential plant oil containing neophytadine [45] (Table 3). Neophytadiene is also reported to possess antibacterial activity as well as helping in the treatment of headaches, rheumatism, and some skin disease [46]. Glycidyl palmitate is a fatty acid with the molecular formula $\mathrm{C}_{19} \mathrm{H}_{3} 6 \mathrm{O}_{3}$ is essential in the preparation of lysophosphatidic acids, which inhibit apoptosis [40,47].

\subsection{Molecular docking.}

To explore the possible mechanism of NO inhibition, a molecular docking approach was executed. The lower the relative binding energy, the more potent the binding affinity between 3JE8 and target molecules. The binding energy of Octadecanoic acid, 2methyloctacosane, and Neophytadiene with the protein were $-8.48,7.62$, and $-6.37 \mathrm{kcal} / \mathrm{mol}$, respectively (Table 4). The remaining 6 compounds, such as cyclopropanetetradecanoic acid, hexadecenoic acid methyl ester, glycidyl palmitate, oxacycloheptadec-8-en-2-one, cyclohexanol, and oxirane, showed the binding energy in the range of 4.52 to $5.89 \mathrm{kcal} / \mathrm{mol}$.

Table 4. Molecular docking analysis.

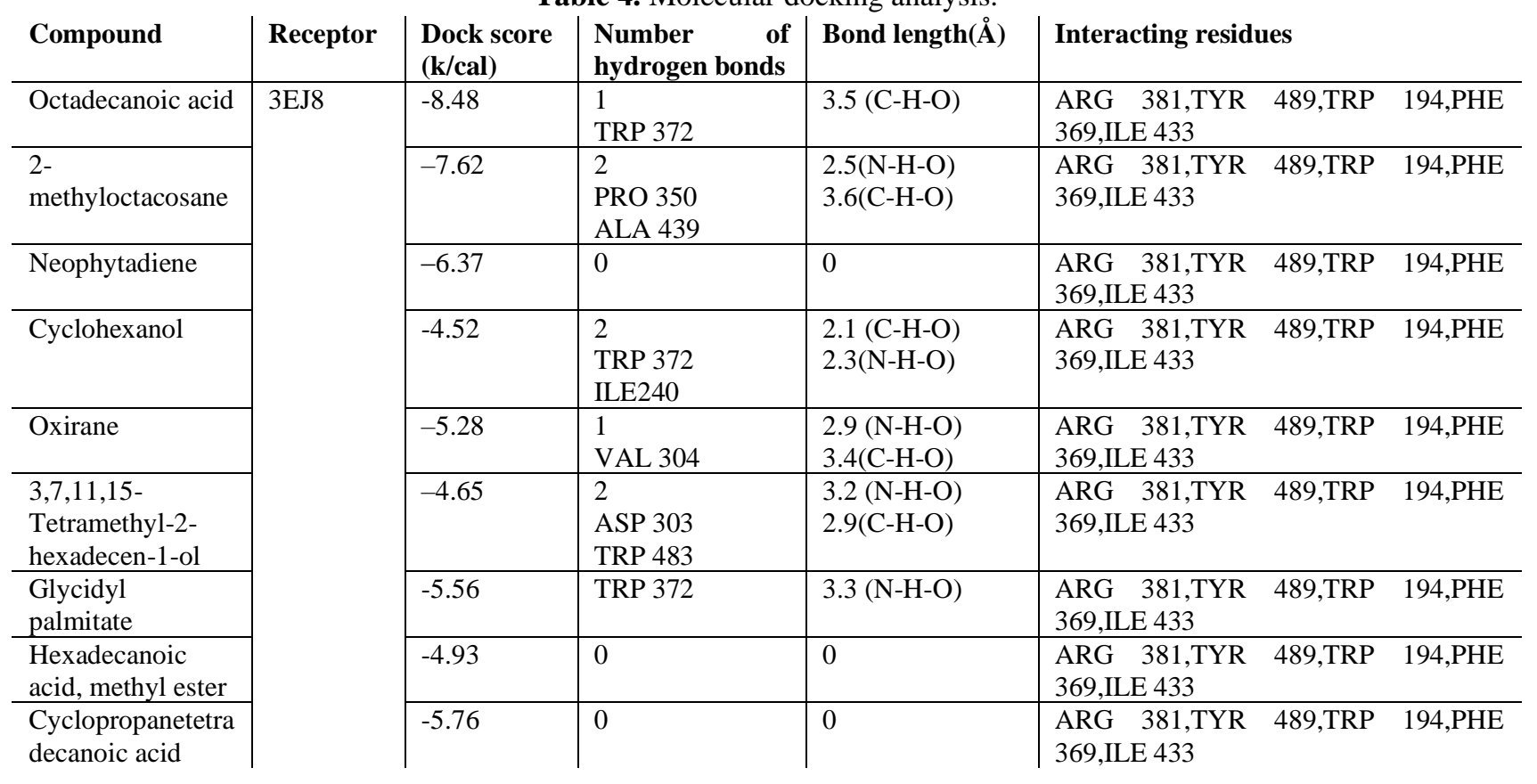

\section{Conclusions}

In this study, various $\alpha$-amylase enzyme inhibition assays ranged from $47.2 \%$ to 58.4 $\%$ for methanol extract and $35.12 \%$ to $51.1 \%$ for aqueous extract. The DPPH radical scavenging activity ranged from $27.6 \%$ to $49.8 \%$ for methanol extract and from $21.3 \%$ to $42.2 \%$ for aqueous extract. The anti-inflammatory activity ranged from $40.5 \%$ to $86.2 \%$ and $49.4 \%$ to $79.2 \%$ for methanol extract and aqueous extract respectively. Cyclohexanol and oxirane were found to be potent drug candidates through molecular docking. 


\section{Funding}

This research received no external funding.

\section{Acknowledgments}

This research has no acknowledgment.

\section{Conflicts of Interest}

The authors declare no conflict of interest.

\section{References}

1. Gasmi, A.; Noor, S.; Menzel, A.; Doşa, A.; Pivina, L.; Bjørklund, G. Obesity and Insulin Resistance: Associations with Chronic Inflammation, Genetic and Epigenetic Factors. Curr Med Chem 2021, 28, 800826, https://doi.org/10.2174/0929867327666200824112056.

2. Ghiasian, M. Microbial biofilms: Beneficial applications for sustainable agriculture. In: New and Future Developments in Microbial Biotechnology and Bioengineering. Elsevier, 2020; pp. 145-155, https://doi.org/10.1016/B978-0-12-820526-6.00009-9.

3. Sharma, P.P.; Pawar, B.T. Cryptogams. Educational Publishers \& Distributors. 2020.

4. Sommer, V.; Karsten, U.; Glaser, K. Halophilic algal communities in biological soil crusts isolated from potash tailings pile areas. Frontiers in Ecology and Evolution, 2020, 8.

5. Cannon, P.; Aptroot, A.; Coppins, B.; Simkin, J.; Otálora, M.; Košuthová, A.; Wedin, M. Revisions of British and Irish Lichens. In: Peltigerales: Collemataceae (including the genera Blennothallia, Callome, Collema, Enchylium, Epiphloea, Lathagrium, Leptogium, Pseudoleptogium, Rostania and Scytinium. Volume 3, 2020.

6. Öztürk, Ş. Lichens: Characteristics, Importance, Uses, and Distribution in Turkey. In: Biodiversity, Conservation and Sustainability in Asia: Volume 1: Prospects and Challenges in West Asia and Caucasus. Volume 39, 2021.

7. Goga, M.; Elečko, J.; Marcinčinová, M.; Ručová, D.; Bačkorová, M.; Bačkor, M. Lichen metabolites: an overview of some secondary metabolites and their biological potential. In: Co-evolution of secondary metabolites. 2020; pp. 175-209.

8. Shukla, I.; Azmi, L.; Shukla, S.K.; Rao, C.V. Contribution of Lichens in Rectification of Alcohol-Induced Liver Damage: Preventive or Curative. In: Innovations in Food Technology. Springer, Singapore. 2020; pp. 201-210.

9. Shahid, M.; Rasool, A.; Anjum, F.; Rehman, M.T. Biomedical Perspectives of Lichen-Derived Products. In: Lichen-Derived Products: Extraction and Applications. 2020; pp. 263-276.

10. Devi, R.; Kaur, T.; Guleria, G.; Rana, K. L.; Kour, D.; Yadav, N.; Saxena, A.K. Fungal secondary metabolites and their biotechnological applications for human health. In: New and Future Developments in Microbial Biotechnology and Bioengineering. Elsevier, 2020; pp. 147-161, https://doi.org/10.1016/B978-0-12-8205280.00010-7.

11. Kosanić, M.; Ranković, B. Lichen secondary metabolites as potential antibiotic agents. In: Lichen secondary metabolites bioactive properties and pharmaceutical potential. Ranković, B. (ed), Springer International Publishing, Springer Cham Heidelberg New York Dordrecht London, 2015; pp. 81-104, https://doi.org/10.1007/978-3-319-13374-4_3.

12. Sachin, M.B.; Mahalakshmi, S.N.; Kekuda, T.R.P. Insecticidal efficacy of lichens and their metabolites-A mini review. Journal of Applied Pharmaceutical Science 2018, 8, 159-164, https://doi.org/10.7324/JAPS.2018.81020.

13. Goga, M.; Elečko, J.; Marcinčinová, M.; Ručová, D.; Bačkorová, M.; Bačkor, M. Lichen Metabolites: An Overview of Some Secondary Metabolites and Their Biological Potential. In: Co-Evolution of Secondary Metabolites. Merillon, J.-M.; Ramawat, K.G. Eds.; Springer International Publishing: Cham, 2018; pp. 1-36, https://doi.org/10.1007/978-3-319-76887-8_57-1.

14. Samrot, A.V., Raji, P.; Selvarani, J.A.; Angalene, L.A.; Sruthi, D.P.; Paulraj, P.; Iyappan, P. A. In: Handbook on Phytochemical extraction, screening and its in-vitro bioactivity assays. SARAS Publications. 2019.

15. Lowry, O.H.; Rosebrough, N.J.; Farr, A.L.; Randall, R.J. Protein measurement with the Folin phenol reagent. The Journal of biological chemistry 1951, 193, 265-275.

16. Wolfe, K.; Wu, X.; Liu, R.H. Antioxidant Activity of Apple Peels. Journal of Agricultural and Food Chemistry 2003, 51, 609-614, https://doi.org/10.1021/jf020782a.

17. Priyadarsini, R.; Durga, V.; Ahmed, S. Virtual screening, synthesis of newer heterocycles as PPAR $\gamma$ agonists with antidiabetic activity. Int J Pharm Sci Res 2017, 8, 631-45, https://doi.org/10.13040/IJPSR.0975$8232.8(2) .631-45$. 
18. Islam, M.T.; Ibrahim, M.; Ahsan, M.Q.; Chowdhury et al. Pharmacological Investigations of Uraria lagopodies DC. and Urena lobata L. Dhaka University Journal of Pharmaceutical Sciences 2012, 11, 65-69, https://doi.org/10.3329/dujps.v11i1.12490.

19. Samrot, A. TLC Bio-autography guided identification of antioxidant and antibacterial activity of Acacia senegal. Der Pharmacia Lettre 2016, 8, 41-47.

20. Samrot, A.V.; Bennet Rohan, D.; Sahiti, K.; Raji, P.; Divya Kumar, M.; Ratna Geethika, G. TLC bioautography guided identification of antioxidant and antibacterial activity of various extracts of Punica granatum. Journal of Chemical and Pharmaceutical Research 2016b. 8, 815-820.

21. Samrot, A.; Rohan, B.; Kumar, D.; Kuppa, S.; P, R.; Kuppa, S.S. Detection of antioxidant and antibacterial activity of Mangifera indica using TLC bio-autography. International Journal of Pharmaceutical Sciences and Research 2016, 7, 4467-4472, https://doi.org/10.13040/IJPSR.0975-8232.7(11).4467-72.

22. Victoria, D.; Samrot, A. TLC bio-autography guided identification of antioxidant fraction from Aegle marmelos rind. Research Journal of Pharmaceutical, Biological and Chemical Sciences 2015, 6, 975-8585.

23. Senthilkumar, N.; Murugesan, S.; Babu, D.; Rajeshkannan, C. GC-MS analysis of the extract of endophytic fungus, Phomopsis sp. Isolated from tropical tree species of India, Tectona grandis L. International Journal of Innovative Research in Science, Engineering and Technology 2014, 3, 10176-10179.

24. Arthi, P.; Shobana, S.; Srinivasan, P.; Prabhu, D.; Arulvasu, C.; Kalilur Rahiman, A. Dinuclear manganese(II) complexes of hexaazamacrocycles bearing N-benzoylated pendant separated by aromatic spacers: Antibacterial, DNA interaction, cytotoxic and molecular docking studies. Journal of Photochemistry and Photobiology B: Biology 2015, 153, 247-260, https://doi.org/10.1016/j.jphotobiol.2015.09.026.

25. Studzińska-Sroka, E.; Dubino, A. Lichens as a source of chemical compounds with anti-inflammatory activity. Herba Polonica 2018, 64, 56-64, https://doi.org/10.2478/hepo-2018-0005.

26. Thadhani, V.M.; Karunaratne, V. Potential of Lichen Compounds as Antidiabetic Agents with Antioxidative Properties: A Review. Oxidative Medicine and Cellular Longevity 2017, 2017, https://doi.org/10.1155/2017/2079697.

27. Judith, T.; Toscane, F. Antimicrobial properties from lichens: An evaluation of the antimicrobial properties of English churchyard lichens. Access Microbiology 2019, https://doi.org/10.1099/acmi.amrmeds2019.po0001.

28. Rashmi, S.; Hengameh, P.; Rajkumar, H.G. Screening Of Lichen Extracts For In Vitro Antidiabetic Activity Using Alpha Amylase Inhibitory Assay. International Journal of Biological \& Pharmaceutical Research 2015, 6, 364-367.

29. Vinayaka, K.S.; Praveen, K.S.V.; Prashith, K.T.R.; Krishnamurthy, Y.L.; Mallikarjun, N and Swathi, D. Proximate Composition,antioxidant, antihelminthic and insecticidal activity of macrolichen Ramalina conduplicans vain. (Ramalinaceae). European Journal of Applied Sciences 2009, 1, 40-46.

30. Kambar, Y.; Vivek, M.N.; Manasa, M.; Mallikarjun, K.S.N.; Prashith Kekuda, T.R. Antimicrobial Activity of Leptogium burnetiae, Ramalina hossei, Roccella montagnei and Heterodermia diademata. Int. J. Pharm. Phytopharmacol. Res. 2014, 4, 164-168.

31. Akbulut, G.; Yildiz, A. An Overview to Lichens: The Nutrient Composition of Some Species. Kafkas Üniv Fen Bil Enst Derg 2010, 3(2), 79-86,.

32. Aoussar, N.; Manzali, R.; Nattah, I.; Rhallabi, N.; Vasiljević, P.; Bouksaim, M.; Douira, A.; Manojlovic, N.; Mellouki, F. Chemical composition and antioxidant activity of two lichens species(Pseudevernia furfuracea L and Evernia prunastri L) collected from Morocco. Journal of Materials and Environmental Sciences 2017, 8, 1968-1976.

33. Parizadeh, H.; Garampalli, R. H.; Chemical composition and correlation study on phytochemicals of some lichen species. International Journal of Pharmacogency 2018, 5, 167-176.

34. Kosanić, M.; Ranković, B.; Vukojević, J. Antioxidant properties of some lichen species. Journal of Food Science and Technology 2011, 48, 584-590, https://doi.org/10.1007/s13197-010-0174-2.

35. Vinayaka, K.S.; Karthik, S.; Nandini, K.C.; Prashith Kekuda T.R. Amylase Inhibitory Activity of Some Macrolichens of Western Ghats, Karnataka, India. Indian Journal of Novel Drug Delivery 2013, 5(4), 225228.

36. Culberson, C.F.; Kristinsson, H.-D. A standardized method for the identification of lichen products. Journal of Chromatography A 1970, 46, 85-93, https://doi.org/10.1016/S0021-9673(00)83967-9.

37. Sajid, M.; Khan, M.R.; Shah, S.A.; Majid, M.; Ismail, H.; Maryam, S.; Batool, R.; Younis, T. Investigations on anti-inflammatory and analgesic activities of Alnus nitida Spach (Endl). stem bark in Sprague Dawley rats. J Ethnopharmacol 2017, 198, 407-416, https://doi.org/10.1016/j.jep.2017.01.041.

38. Abubacker, M.N.; Deepalakshmi, T. In vitro Antifungal Potentials of Bioactive Compound Methyl Ester of Hexadecanoic Acid Isolated from Annona muricata Linn. (Annonaceae) Leaves. Biosciences Biotechnology Research Asia 2013, 10, 879-884, https://doi.org/10.13005/bbra/1211.

39. Penpun, W.; Napaporn, T.; Juree, C. Chemical Constituents and Antimicrobial Activity of Essential Oil and Extracts of Heartwood of Aquilaria crassna Obtained from Water Distillation and Supercritical Fluid Carbon Dioxide Extraction. Silpakorn University Science and Technology Journal 2009, 3, 25-33. 
40. Yakubu, O.; Olawale, O.; Onwuka, J. Gas Chromatography-Mass Spectrometry (GC-MS) Analysis of Aqueous Extract of Daniellia oliveri Stem Bark. Pharmaceutica Analytica Acta 2017, 8, 1-8, https://doi.org/10.4172/2153-2435.1000568.

41. Sonia, S. Phytoconstituents of Ziziphus nummularia (Burm. f.) Wight \& Arn. leaves extracts using GC-MS spectroscopy. Res. Rev. J. Life Sci. 2019, 9, 109-118.

42. Yaouba, S.; Koch, A.; Guantai, E. M.; Derese, S.; Irungu, B.; Heydenreich, M.; \& Yenesew, A. Alkenyl cyclohexanone derivatives from Lannea rivae and Lannea schweinfurthii. Phytochemistry Letters 2018, 23, 141-148, https://doi.org/10.1016/J.PHYTOL.2017.12.001.

43. Kumar, V.; Bhatnagar, A.; Srivastava, J. Antibacterial activity of crude extracts of Spirulina platensis and its structural elucidation of bioactive compound. Journal of Medicinal Plants Research 2011, 5, 7043-7048.

44. Farina Mujeeb, Preeti Bajpai, Neelam Pathak, Phytochemical Evaluation, Antimicrobial Activity, and Determination of Bioactive Components from Leaves of Aegle marmelos. BioMed Research International 2014, 2014, 11, http://dx.doi.org/10.1155/2014/497606.

45. Palic, R.; Stojanovic, G.; Alagic, S.; Nikolic, M.; Lepojevic, Z. Chemical composition and antimicrobial activity of the essential oil and $\mathrm{CO} 2$ extracts of the oriental tobacco, Prilep. Flavour and Fragrance Journal 2002, 17, 323-326, https://doi.org/10.1002/ffj.1084.

46. Lalitharani, S.; Mohan, V.; Regini, G. GC-MS analysis of ethanolic extract of Zanthoxylum rhetsa (roxb.) dc spines. J Herbal Med Toxicol 2010, 4, 191-192.

47. Sistla, R.; Tata, V.S.S.K; Kashyab, T.V.; Chandrasekar, D.; Diwan, P.V. Development and validation of a reversed-phase HPLC method for the determination of ezetimibe in pharmaceutical dosage forms. $J$ Pharm Biomed Anal 2005, 39 (3-4), 517-522. https://doi.org/10.1016/j.jpba.2005.04.026 